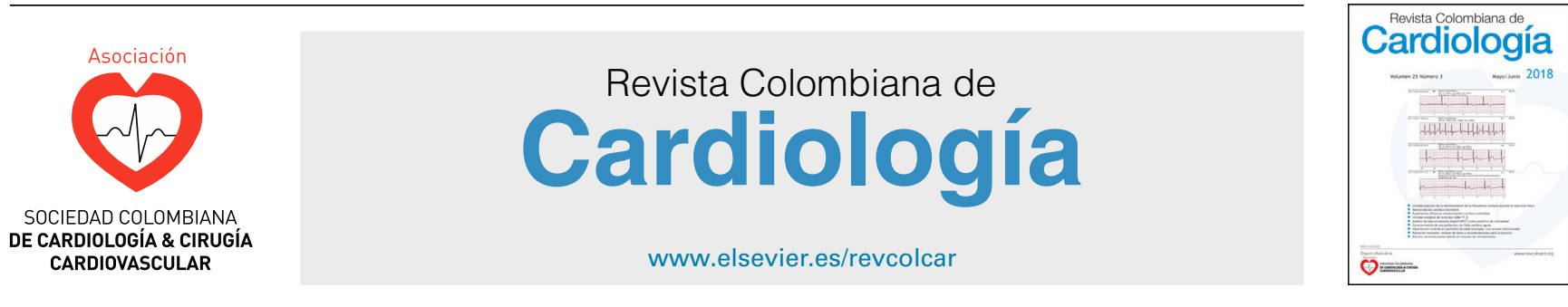

ADULT CARDIOLOGY - ORIGINAL ARTICLES

\title{
Lens changes in cardiovascular catheterization laboratories staff
}

\section{César Hernández ${ }^{\mathrm{a}, *}$, Flor E. Gómez ${ }^{\mathrm{b}}$, María C. Cortés ${ }^{\mathrm{b}}$, Mariana Cabrera ${ }^{\mathrm{b}}$, Claudia R. Carvajal ${ }^{\mathrm{b}}$, Shirley M. Rosenstiehl ${ }^{\mathrm{b}}$, Hernán A. Ríos ${ }^{\mathrm{b}}$}

\author{
a Colegio Colombiano de Hemodinamia e Intervencionismo Cardiovascular, Bogotá, Colombia \\ ${ }^{\mathrm{b}}$ Fundación Oftalmológica Nacional, Bogotá, Colombia
}

Received 20 July 2018; accepted 22 January 2019

Available online 10 July 2019

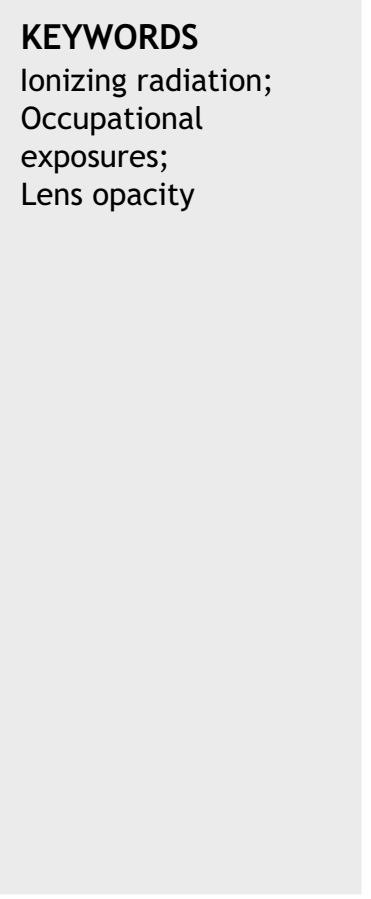

\begin{abstract}
Objective: to determine the association between occupational ionizing radiation exposure in the cardiovascular catheterization laboratories staff and development of lens changes.

Methods: a cross-sectional study was made. Participants were recruited at the XIII Colombian Conference of Interventional Cardiology and SOLACI conferences in Bogotá - Colombia 2017. Informed consent was obtained from all study participants. Demographics and clinical data were collected. Associated lens changes were determined according to the ionizing radiation exposure status.

Results: a total of 89 subjects (178 eyes) participated in the study. In general, the mean age was 40 years old, ranging from 19 to 78 years old. Distribution according gender was $55.3 \%$ male and $44.7 \%$ female. 31 subjects (62 eyes) were deemed to have not occupational exposure to radiation and 58 subjects ( 116 eyes) with a history of occupational radiation exposure. Exposed eyes had twice risk for present subcapsular posterior lens opacity compared to non-exposed eyes. The subjects with older age and physician role were associated to the presence of lens opacity, with a p value 0.001 in both cases. Likewise, exposed subjects with any lens opacity had a high mean occupational lifetime, with a $\mathrm{p} 0.001$.

Conclusions: this study confirms a statistically significant increase in radiation-associated subcapsular lens changes in the eyes of interventional cardiology staff compared to unexposed controls.

(c) 2019 Sociedad Colombiana de Cardiología y Cirugía Cardiovascular. Published by Elsevier España, S.L.U. This is an open access article under the CC BY-NC-ND license (http:// creativecommons.org/licenses/by-nc-nd/4.0/).
\end{abstract}

\footnotetext{
* Corresponding author.

E-mail address: mdcesarhernandez@gmail.com (C. Hernández).
} 


\section{PALABRAS CLAVE}

Radiación ionizante; Xposición ocupacional; Opacidad del cristalino

\section{Cambios en el cristalino en personal de laboratorio de cateterismo cardiovascular}

\section{Resumen}

Objetivo: determinar la asociación entre la exposición a radiación ionizante en el personal de las salas de cateterismo cardiovascular y el desarrollo de cambios en el cristalino.

Métodos: se hizo un estudio transversal. Los participantes fueron reclutados en el XIII Congreso Colombiano de Cardiología Intervencionista y las Conferencias SOLACI en Bogotá - Colombia 2017. Se obtuvo el consentimiento informado de todos los participantes. Se recolectaron datos demográficos y clínicos. Se determinó la asociación entre los cambios en el cristalino y la exposición a la radiación ionizante.

Resultados: un total de 89 sujetos (178 ojos) participaron en el estudio. En general, la edad promedio fue de 40 años, con edades comprendidas entre los 19 años y 78 años. La distribución según el género fue del $55,3 \%$ en hombres y el $44,7 \%$ en mujeres. Se consideró que 31 sujetos (62 ojos) no tenían exposición ocupacional a la radiación y 58 sujetos (116 ojos) presentaban exposición ocupacional a esta. Los ojos expuestos tenían dos veces el riesgo de presentar opacidad subcapsular posterior del cristalino en comparación con los ojos no expuestos. Los sujetos de mayor edad y con rol de médico se asociaron a la presencia de opacidad del cristalino, con un valor $p$ de 0.001 en ambos casos. Del mismo modo, los sujetos expuestos con cualquier opacidad del cristalino tenían una vida laboral más larga, con una $p 0.001$.

Conclusiones: este estudio confirma un aumento estadísticamente significativo en la presencia de cambios en el cristalino en el personal de las salas de cateterismo cardiovascular en comparación con los controles no expuestos.

(c) 2019 Sociedad Colombiana de Cardiología y Cirugía Cardiovascular. Publicado por Elsevier España, S.L.U. Este es un artículo Open Access bajo la licencia CC BY-NC-ND (http:// creativecommons.org/licenses/by-nc-nd/4.0/).

\section{Introduction}

The lens is especially sensitive to ionization from radiation that alters the protein in its organized collagen fibers, making them opaque. The lens changes can range from non-symptomatic mild opacities to visual impartment. ${ }^{1}$ The development of lens changes has been described after some exposure to ionizing radiation, ${ }^{2}$ including after clinical, therapeutic and diagnostic procedures. ${ }^{3,4}$ Professional and ancillary personnel are at risk for developing radiation-induced cataracts since the radiation can have an accumulative effect during life. ${ }^{5}$ Cardiovascular Catheterization laboratories Staff (CCLS) are in particular danger of developing radiation-induced cataracts because their work necessitates their being close to the patient during catheterizations. Variability in the minimum radiation dosage that causes cataracts is also based upon age, illnesses, medications, use of protective apparatus, and an otherwise normal individual's propensity to normally develop cataracts in the absence of radiation exposure. ${ }^{5}$

Between 1980 and 2011 the International Commission on Radiological Protection (ICRP) recommended a lifetime limitation of dose to the lens of $2 \mathrm{~Sv}$ for acute exposure or $5 \mathrm{~Sv}$ for protracted exposure. ${ }^{6}$ But in 2012, because of accumulating epidemiologic evidence that lower radiation doses were also associated with lens opacity development, for occupational exposure the ICRP recommended a lifetime equivalent lens dose limit of $0.5 \mathrm{~Sv}$ and an annual limit of $20 \mathrm{mSv}$ averaged over five years, with no year exceeding $50 \mathrm{mSv}$ in planned exposure situations. ${ }^{7}$

Cardiovascular catheterization laboratories staff are exposed to one of the highest doses of occupational radiation in healthcare, ${ }^{8-11}$ and recent reports have shown detectable lens changes in cardiovascular catheterization laboratories staff, including those with estimated cumulative occupational exposures lower than previously considered dose thresholds. ${ }^{12-16}$

There are different concepts about the amount of exposure that generates changes in the lens, ,5,11,12,14-19 new studies are needed to determine this association and the maximum exposure threshold. The aim of this study was to determine the association between occupational ionizing radiation exposures in the cardiovascular catheterization laboratories staff and development of lens changes.

\section{Methods}

A cross-sectional study was made. Participants were recruited at the XIII Colombian Conference of Interventional Cardiology and SOLACl conferences in Bogotá-Colombia 2017. Informed consent was obtained from all study participants.

According radiation exposed status the participants were classified as exposed or non-exposed subjects. Selection criteria for exposed subjects ware to be physician, nurse and any ancillary personnel exposed to ionizing radiation in a cardiovascular catheterization laboratory. Non-exposed subjects had to meet with no previous exposition to ionizing radiation. Subjects with prior intraocular surgery, ocular trauma, history of uveitis, metabolic or congenital cataract, conditions that did not allow visualization of the lens and subjects with no capacity to understand and sign informed consent were excluded. 
Table 1 Background and demographic characteristics according exposition.

\begin{tabular}{llll}
\hline Variable & Exposed subjects & Non-exposed subjects & Total \\
\hline $\begin{array}{l}\text { Number of subjects } \\
\text { Mean age (range) }\end{array}$ & 58 & 31 & 89 \\
Gender M-F & $40(20-74)$ & $39(19-78)$ & $40(19-78)$ \\
Role \% & $65.5 \%-34.5 \%$ & $33.3 \%-66.7 \%$ & $55.3 \%-44.7 \%$ \\
$\quad$ Physician & & & 0.001 \\
$\quad$ Nurse & 51.7 & 0 & 0.09 \\
$\quad$ Technician & 8.6 & 3.7 & 0.001 \\
$\quad$ Other & 31 & 11.1 & 35.3 \\
\% Smoking & 8.6 & 85.2 & 7.1 \\
\% SH & 22.4 & 14.8 & 24.7 \\
\% DM & 5.2 & 7.4 & 32.9 \\
Dyslipidemia & 1.7 & 0 & 0.64 \\
\hline SH: sistemic hypertension & 13.8 & 7.4 & 0.74 \\
M: male & & & 0.31 \\
F: female & & & \\
DM: diabetes mellitus & & &
\end{tabular}

Study subjects were asked to complete an assistedadministered questionnaire collecting data regarding demographics, occupational history and practice in the cardiovascular catheterization laboratory (years in practice, typical monthly procedure volume, types of procedures performed, and radiation protection), and past medical and ocular history to identify potential confounders (e.g., history of prolonged steroid used, diabetes mellitus, non-occupational exposure to radiation and smoking). Using data from the questionnaire, an estimation of the cumulative doses exposure to radiation was performed according the years in practice and the monthly procedures volume.

Subjects eligible for dilated eye examination underwent slit lamp examination by a three certified ophthalmologist, who ware blinded to subjects exposure status. Tropicamide $1 \%$ ophthalmic solution was administered to achieve mydriasis. Slit lamp examination was performed, and lens opacity was scored in real-time. Lens findings in the posterior subcapsular region were graded in 0.5 point increments using a modified Merriam-Focht Scale (MFS). ${ }^{20}$

For univariable analysis, categorical variables were expressed as percentages and compared between groups (exposed versus control, within the exposed group according to lens findings). For quantitative variables, central tendency and dispersion measurement were calculated (mean and standard deviation), according to the relevance. On bivariate analysis association of qualitative polytomous variables with quantitative variables of normal distribution was made using ANOVA and Kruskal-Wallis test. Statistical analyses were performed using SPSS ver 21 (ser. 572110343). A P-value of $<0.05$ was considered statistically significant. Approval for the study was obtained from the Ethics Committee at Fundación Oftalmológica Nacional.

\section{Results}

A total of 89 subjects (178 eyes) consented to participate in the study and underwent dilated eye examination. Using questionnaire data, 31 subjects (62 eyes) were deemed to have not occupational exposure to radiation and 58 subjects (116 eyes) with a history of occupational radiation exposure. In exposed subjects, $51.7 \%$ were physician, $31 \%$ were technicians, $8.6 \%$ were nurses, and $8.6 \%$ with other roles (industry, research staff, and others). In general, the mean age was 40 years old, ranging from 19 - 78 years old. Distribution according gender was $55.3 \%$ male and $44.7 \%$ female. Complete demographic characteristics, history and their association with lens opacity are described in Table 1. The subjects with older age and physician role were associated to the presence of lens opacity, with a $p$ value 0.001 in both cases. Likewise, exposed subjects with any lens opacity had a high mean occupational lifetime, with a $p 0.001$

Typical monthly number of procedures and types of procedures performed are described in Table 2. The proportion of subjects with a history of chronic steroids use or nonoccupational exposure to radiation was insignificant.

Bivariate analysis was made with the number of eyes. Both eyes of each subject were included for statistical analysis. A multivariate analysis was performed with variables that showed statistically significant association in bivariate analysis. The variables age and years of practice presented multicollinearity, so age was eliminated from the model. The prevalence of lens opacity was low in both exposed and nonexposed groups, $30.3 \%$ of exposed eyes had some kind of subcapsular posterior opacity and only $21 \%$ of non-exposed eyes had it, with a $p$ 0.008. Exposed eyes had twice risk for present subcapsular posterior lens opacity compared to non-exposed eyes (OR 2.49, IC 1.14-5.23). The interobserver variability for subcapsular lens opacity diagnosis was evaluated (according to Merriam-Focht Scale), Kappa index was 0.47 between Ophthalmologist \#1 and Ophthalmologist \#2, and 0.55 between Ophthalmologist \#1 and Ophthalmologist $\# 3$, it was considered as a moderate concordance.

Most subjects used some kind of radiation protection, being lead apron as the most frequent used in $96.6 \%$ of subjects, followed by thyroid collar in $81 \%$ of subjects, lead 
Table 2 Years in practice, number and types of procedures per month ( $n=116$ eyes).

\begin{tabular}{|c|c|c|c|c|c|c|}
\hline & $\begin{array}{l}\text { Years in } \\
\text { practice }\end{array}$ & $\begin{array}{l}\text { Total } \\
\text { procedures }\end{array}$ & $\begin{array}{l}\text { Diagnostic } \\
\text { procedures }\end{array}$ & Angioplasty & $\begin{array}{l}\text { Structural } \\
\text { procedures }\end{array}$ & $\begin{array}{l}\text { Peripheral } \\
\text { interventions }\end{array}$ \\
\hline Median & 8,0 & 100,0 & 51,0 & 25,5 & 3,3 & 3,8 \\
\hline Standard deviation & 9,43 & 53,00 & 40,81 & 16,33 & 7,12 & 7,97 \\
\hline Minimum & 1 & 4 & 0 & 0 & 0 & 0 \\
\hline Maximum & 50 & 250 & 200 & 80 & 40 & 30 \\
\hline \multicolumn{7}{|l|}{ Percentiles } \\
\hline 25 & 4 & 50 & 25 & 15 & 0 & 0 \\
\hline 50 & 8,0 & 100,0 & 51,0 & 25,5 & 3,3 & 3,8 \\
\hline 75 & 15 & 120 & 70 & 36 & 7 & 10 \\
\hline \multicolumn{7}{|l|}{$p^{*}$} \\
\hline (p) & 0,001 & 0,32 & 0,54 & 0,13 & 0,81 & 0,22 \\
\hline
\end{tabular}

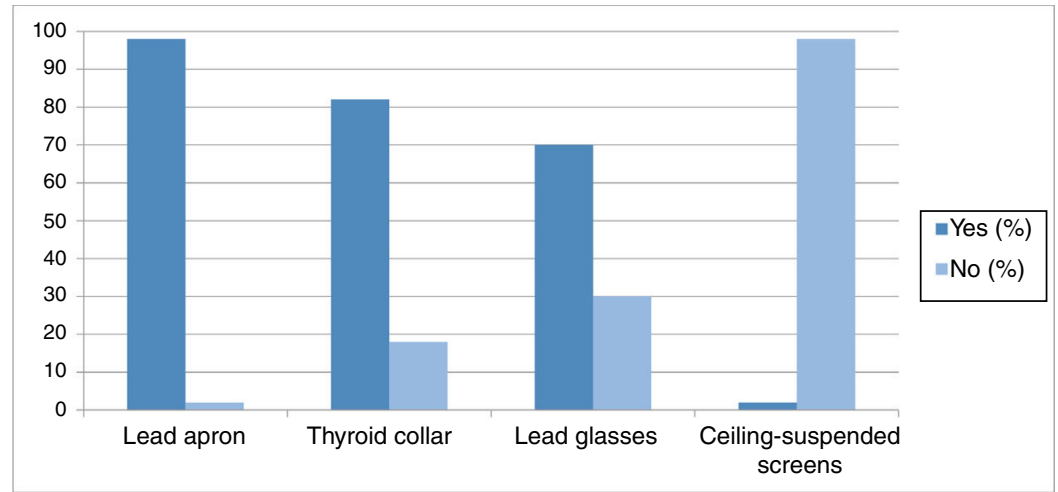

Figure 1 Radiation protection use.

glasses in $69 \%$ of subjects, otherwise only $2 \%$ of subjects reported a ceiling-suspended screens use (fig. 1). The use of the dosimeter is mandatory, however $87.9 \%$ of subjects declared to use it. Within subjects who used dosimeter, less than $20 \%$ knew the last dosimeter report.

\section{Discussion}

Radiation-induced lens opacity has been observed in different exposed populations at lower doses than expected. Instead, several epidemiological studies suggest a nonthreshold effect for lens opacity development. ${ }^{1}$ This study confirms a statistically significant increase in radiationassociated subcapsular lens changes in the eyes of interventional cardiology staff compared to unexposed controls.

From the exposed patients, physician role was associated to the presence of lens opacity, this can be explained by the position of physician during the interventions, different from the rest of the staff. This finding reflects much more attention and the need to provide and guarantee the correct use of all protective measures, even more if the role is physician. Contrary to Matsubaraa findings, ${ }^{21}$ in our exposed subjects with roles different from physician there was not associated with lens opacity.

The posterior lens changes found in the present study may not result in significantly decreased in visual acuity. However, regular ophthalmological examination and followup could elucide such changes progress.

Different from other studies, ${ }^{22}$ ceiling-suspended screens is rare as a protection method in our subjects. Instead, the use of lead apron was the most frequent radiation protection reported. This may be due to the fact that in our country the ceiling-suspended screens are not well distributed and in most catheterization laboratories are limited. In general, most of study subjects reported irregular use of screens, eyeglasses or both in their daily practice. According to the results obtained, the use of these measures should be encouraged.

These results reinforce those of previous studies, ${ }^{9,13,14,21-23}$ however future randomized and controlled studies are needed to determine the amount and effect of radiation on this staff.

This study had some limitations, the power to establish causality is limited due to the type of study and its design. However, this is the first report conducted in Colombia, which describes the characteristics of radiation exposure of this population and compares it with a similar population 
not exposed. These findings are the first step to support adjustments in the regulations within the catheterization laboratories.

\section{Disclosure}

None.

\section{Funding}

Colegio Colombiano de Hemodinamia e Intervencionismo Cardiovascular.

\section{Conflict of interest}

None.

\section{References}

1. Jacob $S$, Michel $M$, Spaulding $C$, Boveda $S$, Bar O, Brézin AP, Streho $M$, et al. Occupational cataracts and lens opacities in interventional cardiology (O'CLOC study): are X-Rays involved? Radiation-induced cataracts and lens opacities. BMC Public Health. 2010;10:537.

2. Brown NP. The lens is more sensitive to radiation than we had believed. Br J Ophthalmol. 1997;81:257.

3. Klein BE, Klein R, Linton KL, Franke T. Diagnostic x-ray exposure and lens opacities: the Beaver Dam Eye Study. Am J Public Health. 1993;83:588-90.

4. Hall P, Granath F, Lundell M, Olsson K, Holm LE. Lenticular opacities in individuals exposed to ionizing radiation in infancy. Radiat Res. 1999;152:190-5.

5. Schultz GR. Radiation-associated cataracts among interventional physicians and support staff. J Indian Coll Cardiol. 2016;6(Supp.1):102-4.

6. International Commission on Radiological Protection. The 2007 Recommendations of the International Commission on Radiological Protection. ICRP publication 103. Ann ICRP. 2007; 37(2-4):9-34.

7. Stewart FA, Akleyev AV, Hauer-Jensen M, Hendry JH, Kleiman NJ, Macvittie TJ, et al. ICRP publication 118: ICRP statement on tissue reactions and early and late effects of radiation in normal tissues and organs-threshold doses for tissue reactions in a radiation protection context. Ann ICRP. 2012;41(1-2):1-322.

8. Delichas M, Psarrakos K, Molyvda-Athanassopoulou E, Giannoglou G, Sioundas A, Hatziioannou K, et al. Radiation exposure to cardiologists performing interventional cardiology procedures. Eur J Radiol. 2003;48:268-73.

9. Kim KP, Miller DL, Balter S, Kleinerman RA, Linet MS, Kwon $D$, et al. Occupational radiation doses to operators performing cardiac catheterization procedures. Health Phys. 2008;94: 211-27.

10. Vano E. Radiation exposure to cardiologists: how it could be reduced. Heart. 2003;89:1123-4.

11. Rehani MM, Ortiz-Lopez P. Radiation effects in fluoroscopically guided cardiac interventions-keeping them under control. Int J Cardiol. 2006;109:147-51.

12. Bitarafan-Rajabi A, Noohi F, Hashemi H, Haghjoo M, Miraftab $M$, Yaghoobi N, et al. Ionizing Radiation-Induced Cataract in Cardiology Interventional Staff During Coronary Interventional Procedures. Res Cardiovasc Med. 2015;4:e25148.

13. Jacob S, Boveda S, Bar O, Brézin A, Maccia C, Laurier D, et al. Interventional cardiologists and risk of radiation-induced cataract: results of a French multicenter observational study. Int J Cardiol. 2013;167:1843-7.

14. Mrena S, Kivelä T, Kurttio P, Auvinen A. Lens opacities among physicians occupationally exposed to ionizing radiation - a pilot study in Finland. Scand J Work Environ Health. 2011;37: 237-43.

15. Vano E, Kleiman NJ, Duran A, Rehani MM, Echeverri D, Cabrera M. Radiation Cataract Risk in Interventional Cardiology Personnel. Radiat Res. 2010;174:490-5.

16. Ciraj-Bjelac O, Rehani MM, Sim KH, Liew HB, Vano E, Kleiman NJ. Risk for radiation-induced cataract for staff in interventional cardiology: Is there reason for concern? Catheter Cardiovasc Interv. 2010;76:826-34.

17. Vano E, Kleiman NJ, Duran A, Romano-Miller M, Rehani MM. Radiation-associated lens opacities in catheterization personnel: Results of a survey and direct assessments. J Vasc Intery Radiol. 2013;24:197-204.

18. Shore RE. Radiation and cataract risk: Impact of recent epidemiologic studies on ICRP judgments. Mutat Res. 2016;770: 231-7.

19. Papp C, Romano-Miller M, Descalzo A, Michelin S, Molinari A, Rossini A, et al. Results of relid study 2014-Buenos Aires Argentina retrospective evaluation of lens injuries and dose. Radiat Prot Dosimetry. 2017;173:212-7.

20. Merriam GR, Focht EF. A clinical and experimental study of the effect of single and divided doses of radiation on cataract production. Trans Am Ophthalmol Soc. 1962;60:35-52.

21. Matsubara K, Lertsuwunseri V, Srimahachota S, Krisanachinda A, Tulvatana W, Khambhiphant B, et al. Eye lens dosimetry and the study on radiation cataract in interventional cardiologists. Phys Medica. 2017;44:232-5.

22. Karatasakis A, Brilakis HS, Danek BA, Karacsonyi J, MartinezParachini JR, et al. Radiation-associated lens changes in the cardiac catheterization laboratory: Results from the IC-CATARACT (CATaractsAttributed to RAdiation in the CaTh lab) study. Catheter Cardiovasc Interv. 2018;91: 647-54.

23. Ciraj-Bjelac O, Rehani M, Minamoto A, Sim KH, Liew HB, Vano E. Radiation-induced eye lens changes and risk for cataract in interventional cardiology. Cardiology. 2012;123:168-71. 